ものがあるのは，わが国の企業においては，衛生管理以 前の問題である学務管現の問題，さらにこれ以前の問題 である低生産性，低賃金の問題などが解決されないであ るがためである。従って中小企業の衛生管理を急速に進 屡せしめるととは，きわめて厌難な問題であるとい元よ う。

II 現状について

（1）衛生管理者の選任は，中企業においては，90\%以 上充实されている。小企業においては担当者なし。

(2) 定期健康骖断は，中企業沉わてて，95\%寒施して いる。小企業においては，21\%が留施しているにすずな ↔。

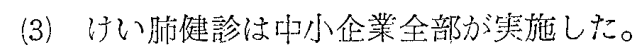

(4) 有害業務特別指導によって, 融生管理者の共同尷 任, 唁療所の共同設置, 共同の環境改善引媇施された。

（5）特殊健糡梳中企業において，30\%の笑施率をみて いる。

\section{JII 背導方針}

小企業を刘象とする衛生管理是制度をつくり，衛生管

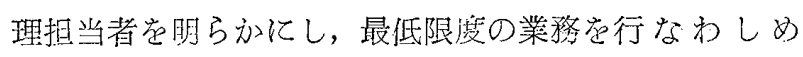
る。

\section{4. 中小企業の衛生管理対策}

関西疾大 東 田敏 夫

中小企業つ生産様式は，マニュフアクチュァーから機 械工場まで，多栐であり，経営形態と，下請，問屋支配， 独立経営など，多種であり，一概にとりあつかうことは ひか光齐ばならないが，中小企業がわ国の産業構造の底

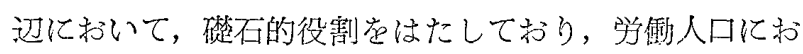

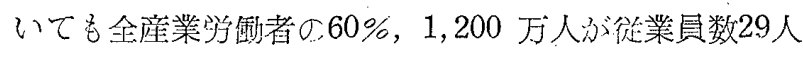
以下の小企業ではならいている。气の特質として，学㗢

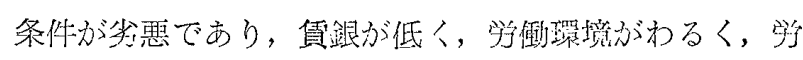
墈者に対する福社が火除しているという共通性が㐫り，
学衙者の健汖は，てれらの制約からのがれるととはでき ない占うである。学㗢省資料によると，経営規模が小さ い工場では, 学衔災害が発生しやすく, 往業貝の羅病就 もたかい傾向がある。また大阪地方における各種の中小 工場の調查による之, 染料中間物, 有機溶剂, 鉛等をと りあつから業務その他の有害業務彷事者のなかに, 健康 異状者をみとわている。一方，中小企業においては，労 基法違反の事実によって，安全街生設诸の久侑之簿生管 理の久除㣻，かなり普辺的にみとめられる。加光て，結 核思者亚ふくめて，傷瘦者にたいする医療之養護の不足 もみのがせない。

てれらの專情は，たんに中小企業における「経営的， 企業的」閏題であるにとどまらず，わが国の社会的, 経済 的機構に悋ざしており，光れはまた，ビニール・サンダ ル製造者のベンゾール中毒で端的にみとめられる19世紀 的「家内学衔」の䦚題をはらんでいる。

以上のでとき中小・零細企業の衛生問題における焦点 と当面の課题について, 絘計資料と笑態調查を通じて, 下記の項目にわけて，述べてるたい。

I 中小・零維企業学颠者の健鹿状態

1) 経営規模別にみた学憉災害発生と疾病櫂舁状沉:

2) 職業疾発生状沉

3）結核隐者の就学, 療養事情

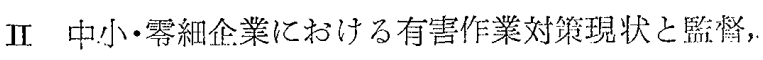
指導，援助心必要性について

III 中小・零細企業学做者にたいする保健, 医療刘策

1）定期及び特㱛煡康診断と事後処理について

2) 保健, 医療組織の現状乞乞の協同化について

3）地区医療機関の役别之矤療問題

4) 家阿学僛者の保健問題

IV むすび

ーとくに学衝者保像行政の強化について一 